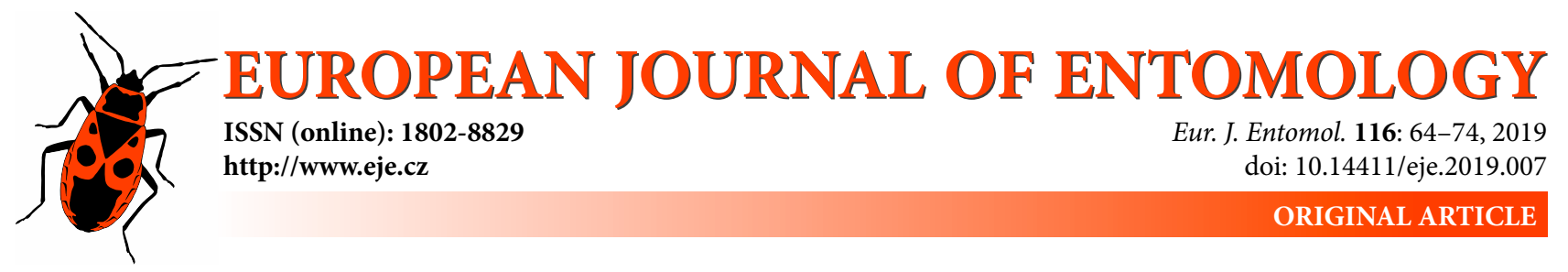

\title{
When is a tree suitable for a veteran tree specialist? Variability in the habitat requirements of the great capricorn beetle (Cerambyx cerdo) (Coleoptera: Cerambycidae)
}

\author{
Michal PlateK $^{1,2}$, Pavel SEBEK $^{1}$, David HAUCK $^{1}$ and Lukas CIZEK $^{1,2}$ \\ ${ }^{1}$ Biology Centre of the Czech Academy of Sciences, Institute of Entomology, Branisovska 31, CZ-37005 Ceske Budejovice, \\ Czech Republic; e-mails: platasplatas@seznam.cz, pav.sebek@gmail.com, dhauck@centrum.cz, lukascizek@gmail.com \\ ${ }^{2}$ Faculty of Science, University of South Bohemia, Branisovska 1760, CZ-37005 Ceske Budejovice, Czech Republic
}

Key words. Coleoptera, Cerambycidae, saproxylic beetles, deadwood, conservation management, old trees, veteran trees, habitat requirements, realized niche, site-specific patterns, great capricorn beetle, Cerambyx cerdo

\begin{abstract}
Large veteran trees are key structures sustaining biodiversity in wooded landscapes. Many organisms associated with such trees are, however, also able to inhabit suitable trees with smaller diameters or other surrogate habitats. Understanding the mechanisms behind the importance of veteran trees and the conditions enabling veteran tree specialists to exploit smaller trees might help conservation efforts targeted at the diverse and highly endangered biota associated with veteran trees. To investigate this, we studied local patterns in the exploitation of trees by a veteran tree specialist, the great capricorn beetle (Cerambyx cerdo), at three sites with different soil characteristics, namely floodplain, dry-sandy and dry-rocky sites, where this beetle exploits oaks of large $(\sim 1.5 \mathrm{~m})$, medium $(\sim 0.75 \mathrm{~m})$ and small $(\sim 0.25 \mathrm{~m})$ diameters, respectively. We recorded the presence and number of exit holes made by C. cerdo on each tree and related these to the characteristics of the trees: their diameters, openness of the canopy around them and their state of health. The probability of occurrence and the number of exit holes increased with tree diameter, canopy openness, and decreasing tree health, but these relationships differed considerably among the study sites. In dry conditions, trees of small diameters were more likely to be exploited by the beetle than in the floodplain. The number of exit holes, on the other hand, was a function of tree diameter, with large trees sustaining more beetles and thus acting as larger habitat patches. The species of oak affected the probability of exit hole presence as the sessile oak (Quercus petraea) and pedunculate oak ( $Q$. robur) were preferred over Turkey oak (Q. cerris). The slope orientation also affected the presence of exit holes as trees on slopes with either an eastern or northern orientation were not exploited by the beetle. This study revealed a high level of between-site variability in the tree characteristics relevant to predicting the occurrence of $C$. cerdo, mainly with respect to diameter. Therefore, while the general patterns of habitat use and the fundamental niche of this beetle are well known, survival and protection of local populations is dependent on site-specific characteristics. The realized niche of this beetle must therefore be carefully considered when planning conservation management for a particular site. The results also signify that at some sites, small trees can, at least temporarily, substitute for scarce large trees if the state of their health is managed using proper conservation measures.
\end{abstract}

\section{INTRODUCTION}

Large veteran trees provide deadwood and a wide range of deadwood-related microhabitats, such as hollows, bare wood and fungal fruiting bodies, which offer feeding opportunities for highly diverse assemblages of biota (Siitonen \& Ranius, 2015). Due to this, veteran trees are key structures for sustaining biodiversity in wooded landscapes (Buse et al., 2008; Lindenmayer et al., 2014). Large veterans occur primarily in open places that have escaped intensive forestry or agricultural practices, such as savannas, wood pastures, avenues, hedgerows, orchards, game reserves or parks (Manning et al., 2006; Siitonen \& Ranius, 2015; Horák, 2017; Miklín et al., 2018). Open woodlands support rich communities of animals including many lightdemanding species that cannot be found under closed can- opies (Ranius \& Jansson, 2000; Sebek et al., 2016; Horák et al., 2018; Parmain \& Bouget, 2018). Open conditions also help trees to attain large dimensions and age slowly, due to the absence of competition from younger trees (Drobyshev et al., 2008; Miklín et al., 2018). Large old trees are especially important for saproxylic (i.e. deadwood dependent) organisms (Siitonen \& Ranius, 2015; Horák, 2017). By slowly ageing, living veteran trees provide deadwood and associated microhabitats for decades, therefore creating temporal continuity in the availability of deadwood resources. This is in contrast with already dead trees, which can offer such habitats only temporarily before they decay.

However, there has been a rapid global decline in the abundance of large veteran trees (Irmler et al., 1996; Read, 2000; Andersson \& Östlund, 2004; Lindenmayer et al., 
2012, 2014) and this has led to their associated specialists becoming highly endangered (Ranius, 2002; Siitonen \& Ranius, 2015). In areas with numerous large old trees there is often a lack of young trees (Alexander, 1998; Bergmeier et al., 2010; Miklín \& Čížek, 2014), leading to a potential gap in availability of old trees in the future, and thus to a temporal discontinuity in this precious habitat. Hence, bridging this gap in the availability of veteran trees is currently one of the main problems in the conservation of biodiversity in temperate regions (Gibbons et al., 2008; Miklín et al., 2018).

In order to propose conservation recommendations for overcoming the lack of veteran trees, knowledge of the fundamental demands of veteran tree specialists is needed. Trees or deadwood of large diameter are often mentioned as an important resource for many endangered saproxylic species (Gossner et al., 2013; Seibold et al., 2015; Eckelt et al., 2018; Kostanjsek et al., 2018), but many insects are at least occasionally able to exploit other habitats, such as younger and thinner trees or accumulated plant matter. For example, a model saproxylic beetle, the hollow specialist Osmoderma s.l. eremita mainly inhabits large hollow trees, but occasionally it is recorded in small trees with diameters of around $25 \mathrm{~cm}$ (Ranius et al., 2005; Barnouin et al., 2017). Deadwood of small diameter (around $20 \mathrm{~cm}$ ) and even wood chips may serve as a habitat for larvae of another model beetle, the stag beetle Lucanus cervus (Harvey et al., 2011). In addition, the great capricorn beetle, Cerambyx cerdo, can also complete its development in large branches or occasionally in trees with a diameter less than $20 \mathrm{~cm}$ (Schwenke, 1974; Kimoto et al., 2006). It is still unclear as to what extent such marginal habitats may facilitate the long-term survival of organisms generally associated with large veteran trees. Furthermore, there is limited knowledge about the conditions that facilitate the exploitation of such marginal habitats (Ranius, 2007; Harvey et al., 2011; Macagno et al., 2015). Moreover, since habitat requirements may vary with biotic and/or abiotic conditions (Freese et al., 2006; Strausz et al., 2012), information on the requirements obtained in one part of a species' distributional range, or habitat type, may not be relevant elsewhere, thus hampering conservation efforts (Cromsigt et al., 2012).

The great capricorn beetle, Cerambyx cerdo Linnaeus 1758 (Cerambycidae), develops in the subcortical zone of trunks, branches and roots of open-grown old or weakened oaks (Quercus spp.) (Buse et al., 2007). Inhabited trees can be identified by typical oval exit (emergence) holes up to a width of $20 \mathrm{~mm}$ (Ehnström \& Axelsson, 2002; Buse et al., 2007). This beetle is distributed throughout the Mediterranean region, Central Europe and the Caucasus (Bily \& Mehl, 1989; Sláma, 1998; Sama, 2002). It is rare and declining in the northern parts of its European range (Sláma, 1998; Starzyk, 2004; Ellwanger, 2008; Jurc et al., 2008). Due to this, the beetle is listed as near threatened in the European Red List of saproxylic beetles (Cálix et al., 2018) and is also included in Appendix II and IV of the EU's Habitats Directive (Council of the European Communities,
1992), which specifies species of special conservation interest. It is considered to be an ecosystem engineer; the damage to trees caused by its larvae creates favourable conditions for many other saproxylic insects (Buse et al., 2008). Although closely associated with large trees (Buse et al., 2007; Albert et al., 2012), C. cerdo occasionally develops in small trees (Sláma, 1998). Therefore, it is a good model for investigating the variability in habitat requirements of saproxylic insects. Understanding the conditions that enable this beetle to exploit small trees might help to bridge a future gap in availability of veteran trees at currently inhabited sites, and thus increase the effectiveness of conservation measures aimed at this beetle and possibly also other veteran tree specialists.

To address the above issues, we recorded the parameters of trees locally exploited by three populations of C. cerdo. One population inhabits large trees growing on a floodplain, another inhabits medium-sized trees growing on dry sandy deposits, and the last population depends solely upon small trees growing on steep, rocky slopes of a river canyon. In order to reveal general and site-specific patterns in the exploitation of trees, we tested (i) whether the relationship between the probability of $C$. cerdo occurrence on trees and the characteristics of trees or their surroundings (diameter, canopy openness and state of tree health) differs among the sites, (ii) whether the relationship between the number of $C$. cerdo exit holes on a tree and the tree's characteristics differs among the sites, and (iii) whether species of oak or slope orientation affect the probability of $C$. cerdo occurrence and the number of its exit holes on trees.

\section{MATERIAL AND METHODS}

\section{Study sites}

This study was conducted at three sites inhabited by C. cerdo populations in South Moravia, Czech Republic. Each site is covered with a different type of woodland because of the abiotic conditions, such as terrain, humidity and substrate (Fig. 1).

The sampling included:

(i) Floodplain site covered by woodlands growing on mostly humid, nutrient rich soils in the Soutok game reserve $\left(48^{\circ} 43^{\prime} \mathrm{N}\right.$, $16^{\circ} 55^{\prime} \mathrm{E}$; $150 \mathrm{~m}$ a.s.1.; mean annual temperature $9.5^{\circ} \mathrm{C}$; mean annual rainfall $\sim 600 \mathrm{~mm}$ ). There are large (diameters mostly $>1$ $\mathrm{m}$ ) and mostly open-grown, veteran pedunculate oaks (Quercus robur) in meadows at this site. For detailed information on the area and its woodland cover see Miklín \& Čížek (2014).

(ii) Dry-sandy site covered by a thermophilous oak woodland on nutrient poor, dry sands of a river terrace in the Rendezvous National Nature Monument $\left(48^{\circ} 45^{\prime} \mathrm{N}, 16^{\circ} 47^{\prime} \mathrm{E}\right.$; $200 \mathrm{~m}$ a.s.l.; mean annual temperature $9.5^{\circ} \mathrm{C}$; mean annual rainfall $\sim 500 \mathrm{~mm}$ ). There are semi-open stands of mostly old (up to 270 years) and mainly formerly coppiced Turkey oak (Q. cerris), pedunculate oak $(Q$. robur $)$ and sessile oak (Q. petraea) of medium size (trunk diameters $<1 \mathrm{~m})$ at this site.

(iii) Dry-rocky site covered by a xeric, dry woodland on nutrient poor, shallow soils on the steep, rocky slopes of the Dyje River canyon in the eastern part of the Podyji National Park $\left(48^{\circ} 49^{\prime} \mathrm{N}, 15^{\circ} 58^{\prime} \mathrm{E} ; 250-350 \mathrm{~m}\right.$ a.s.1.; mean annual temperature $8.8^{\circ} \mathrm{C}$; mean annual rainfall $\sim 560 \mathrm{~mm}$ ). There are mostly semiopen, formerly coppiced sessile oak ( $Q$. petraea) stands both small in height and diameter (diameters mostly $<40 \mathrm{~cm}$ ) at this site. The absence of large trees inhabited by C. cerdo in the wider 


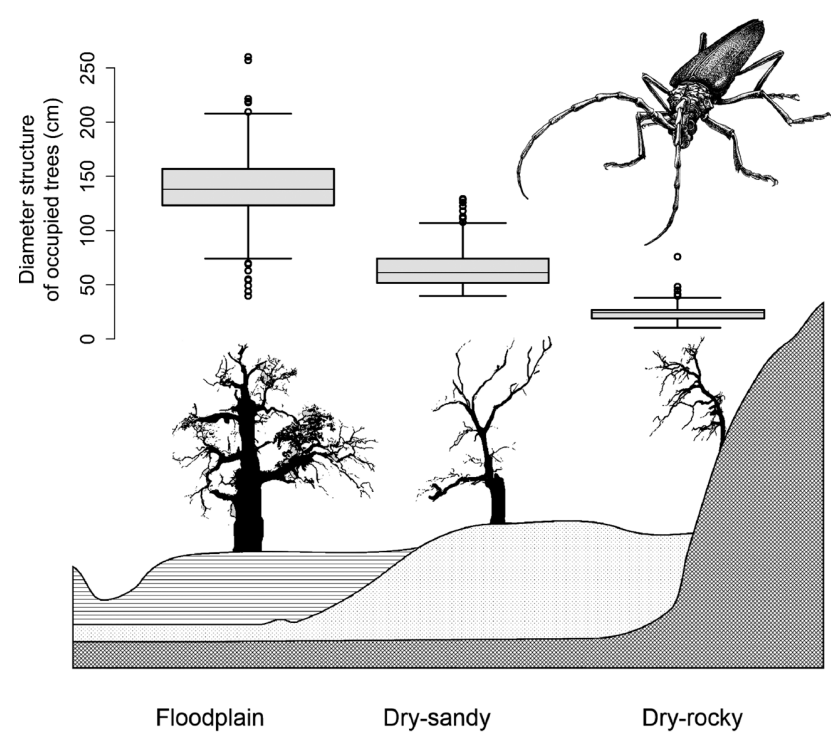

Fig. 1. Characteristic forms of the oaks that are potentially exploitable by Cerambyx cerdo at the three sites studied and the structure of the diameter of the trees occupied by this beetle (DBH in $\mathrm{cm})$.

surroundings of this site demonstrates the ability of this beetle to survive without large trees. For detailed information on this site, see Miklín et al. (2016).

The dry-sandy site is seven $\mathrm{km}$ from the floodplain site and five $\mathrm{km}$ from the nearest floodplain woodland inhabited by the beetle. The dry-rocky site is $>60 \mathrm{~km}$ from both of the other two sites. Molecular genetic analysis indicates that the populations at the floodplain and dry-sandy sites are connected (Drag \& Cizek, 2015), while the population inhabiting the dry-rocky site is most likely isolated.

\section{Sampling strategy}

At each site, oaks occupied by or potentially suitable for the great capricorn beetle were inspected for the presence of typical, up to $20 \mathrm{~mm}$ wide, oval-shaped exit holes of C. cerdo. For each tree, the presence/absence of exit holes and the number of exit holes were recorded. On the lower parts of the trunk, from 0 to $2.5 \mathrm{~m}$ above ground, we counted all the exit holes, higher up on the trunk, the number of exit holes was checked visually using binoculars and counted, or if too numerous to count the number was estimated. The number of exit holes up to $2.5 \mathrm{~m}$ and higher were then summed. Although estimating the number of exit holes higher up on the trunk may increase observation bias, we consider it negligible, as it is mostly the lower part of trunk that is used by the beetle (Albert et al., 2012). Moreover, we recorded the characteristics of each tree and its surroundings, such as the diameter at breast height (DBH), the tree's state of health (a gradient from healthy to nearly dead) and the openness of the canopy around the tree (a gradient from fully closed to fully open) (Table 1). At the dry-sandy site, we also recorded the species of oak and at the dry-rocky site, we recorded the orientation of the slope as the terrain there is hilly.

At (i) the floodplain site, the inventory included oaks in mostly open and semi-open conditions with DBH $>40 \mathrm{~cm}$ within a selected area of $\sim 600$ ha in July 2006 . At the two dry sites, the forest canopy is generally more open. At (ii) the dry-sandy site, details of all the oaks with $\mathrm{DBH}>40 \mathrm{~cm}$ were recorded within the selected area of ca. 6.5 ha in July 2015, and at (iii) the dry-rocky site, the information for trees with $\mathrm{DBH}>10 \mathrm{~cm}$ was recorded along 44 transects of $10 \times 50 \mathrm{~m}$, in an area covering 2.2 ha in July 2010 . The different size of the sampling areas reflects the low density of the trees sampled at the floodplain site and the limited area of suitable habitat at the other sites. We did not include standing dead trees in this study (Table 1) as such trees are unsuitable for the beetle; although in recently dead trees larvae can finish their development, females of the beetle do not lay eggs in dead trees. We inspected altogether 198, 515 and 353 trees at the floodplain, dry-sandy and dry-rocky sites, respectively, i.e. 1,066 trees in total (Table 2). The threshold DBH values were set following preliminary surveys carried out at each site in order to determine the minimum DBH values of trees locally used by the beetle (Fig. 1).

The position of each tree measured was located using GPS, except for the dry-rocky site, where only 176 trees out of 353 were located. This was because the distance between trees was often lower than the GPS precision, and the trees were thus recorded along transects. Based on GPS coordinates, we created a distance matrix of all trees with their spatial position marked (altogether 889 trees). For each of these trees we recorded the shortest distance to a measured tree occupied by $C$. cerdo, and thus created a variable representing distance to the nearest occupied tree. We included this variable in the statistical analysis (see below) but using a smaller dataset containing only trees with GPS locations.

To further describe the sites, we determined the radial growth of oaks. At each site, 4-17 randomly selected trees were cored using a steel increment borer (Mora ${ }^{\mathrm{TM}}$, Sweden). All cores were dried, glued onto a wooden lath, cut using a razor blade and inspected for injuries, reaction wood and other aberrant features. Tree rings were counted from pith to bark and their widths meas-

Table 1. Environmental variables measured for each of the trees inspected.

\begin{tabular}{|c|c|c|}
\hline Variable & Description & Type \\
\hline Health & $\begin{array}{c}\text { State of health of tree on a scale } 0-4 \text { (according to percentage of dead crown: } 0=\text { healthy tree, } \\
4=\text { nearly dead). Dead trees were not included in this study. }\end{array}$ & Continuous \\
\hline Openness & $\begin{array}{l}\text { Visual estimation of the openness of the canopy in immediate surroundings of the measured tree } \\
\text { (the degree to which the tree is shaded by crowns of surrounding trees or shrubs), } \\
\text { on a scale } 0-10 \text { ( } 0=\text { fully closed, } 5=\text { half open, } 10=\text { fully open) }\end{array}$ & Continuous \\
\hline Diameter & Diameter of trunk at breast height $(1.3 \mathrm{~m}$ above ground; $\mathrm{DBH})($ in $\mathrm{cm})$ & Continuous \\
\hline Site & Site affiliation: Floodplain, Dry-sandy, Dry-rocky & Categorical \\
\hline Slope orientation & $\begin{array}{l}\text { Cardinal direction of the slope (exposed to North, East, South, West; or flat); } \\
\text { only recorded at the dry-rocky site. }\end{array}$ & Categorical \\
\hline Tree species & Quercus cerris, Q. petraea or Q. robur, only recorded at the dry-sandy site. & Categorical \\
\hline $\begin{array}{l}\text { Nearest } \\
\text { occupied tree* }\end{array}$ & $\begin{array}{l}\text { Distance to the nearest measured tree occupied by Cerambyx cerdo. } \\
\text { Computed from the distance matrix of all trees whose GPS coordinates were located. }\end{array}$ & Continuous \\
\hline
\end{tabular}

* At the dry-rocky site, not all the trees were located using GPS and therefore the distance to the nearest occupied tree was only included and tested in analyses on a smaller dataset with all the trees from the other sites, but only 176 trees from the dry-rocky site. See Materials and Methods and Supplementary Material. 
ured to the nearest $0.01 \mathrm{~mm}$ using a TimeTable device and PAST4 software (SCIEM, 2012). Mean tree ring widths (and standard deviation) were: $3.13 \mathrm{~mm}$ per year (0.76) at the floodplain, 1.02 $\mathrm{mm}$ per year $(0.18)$ at the dry-sandy and $0.87 \mathrm{~mm}$ per year $(0.28)$ at the dry-rocky site.

\section{Statistical analysis}

We tested the effect of tree characteristics on the occurrence and number of $C$. cerdo exit holes on trees. In order to compare general and site-specific patterns in the exploitation of trees by $C$. cerdo, we fitted two types of regression models: generalized linear and generalized linear mixed-effect models. Presence/absence data (occurrence) and number of exit holes (count data) served as dependent variables in specific models.

In order to filter out the effect of site and thus reveal general patterns, we fitted generalized linear mixed-effect models using a binomial distribution (logit link) and Poisson distribution (log link) for presence/absence data and for number of exit holes, respectively. In both models, diameter, health and openness were explanatory variables and site a random factor variable. The models were built using forward selection procedure; only significant terms were left in final models. The models were fitted using the Generalized Estimating Equations algorithm (Hojsgaard et al., 2006).

To test whether the effect of tree characteristics differed among the sites studied, we fitted generalized linear models using a binomial distribution (logit link) and quasi-Poisson distribution ( $\log$ link) for presence/absence data and number of exit holes, respectively. In both models, diameter, health, openness and site were explanatory variables. After fitting the models using forward selection procedure, we also tested the interaction terms of diameter, health and openness with site and included them in final models if significant.

To test the potential effect of distance to the nearest occupied tree, we then repeated the procedure but with a smaller dataset containing only the 889 trees with GPS locations. The variable nearest occupied tree was included in the forward selection procedure together with the other three variables.

Moreover, as we had the information on the species of oak at the dry-sandy site and information on slope orientation at the dryrocky site, we tested to what extent these might affect the results at a particular site. We created separate models for each of the sites, firstly testing the effects of diameter, health, openness and tree species on the occurrence and the number of exit holes on trees for the dry-sandy site, and secondly testing the effects of diameter, health, openness and slope orientation on the occurrence and the number of exit holes on trees for the dry-rocky site.

All the analyses were carried out using R 3.3.3 (R Core Team, 2017); generalized linear mixed-effect models were performed using the geepack package (Hojsgaard et al., 2006).
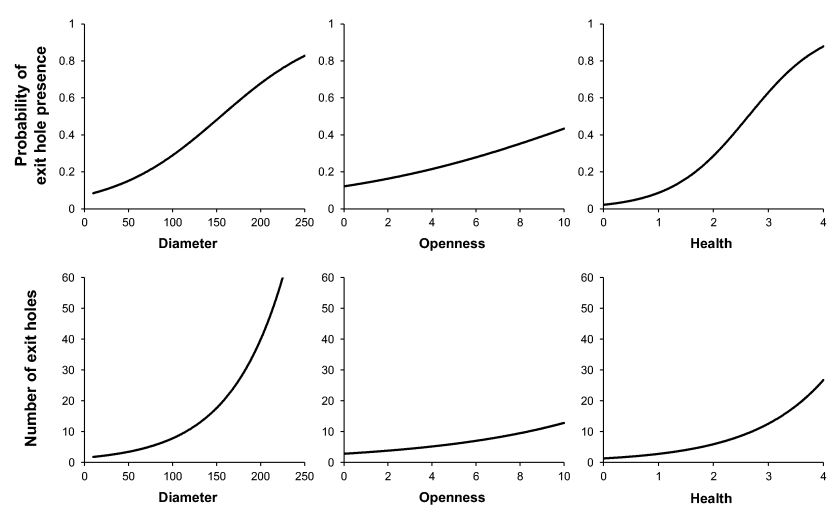

Fig. 2. Predicted probability of occurrence (top row) and number of $C$. cerdo exit holes (bottom row) in relation to three significant variables: diameter, openness, state of health of tree; based on generalized linear mixed-effect models with binomial and Poisson distributions, respectively.

\section{RESULTS}

Altogether, 1,066 oaks were inspected at the three sites. In total, 15,424 C. cerdo exit holes were recorded on 307 trees (see Table 2 for the summary of field data).

\section{General patterns}

All three variables, diameter, openness and tree health, had a significant effect on the occurrence of $C$. cerdo exit holes on trees (diameter: $\chi_{(1)}^{2}=26.9, \mathrm{P}<0.0001$; openness: $\chi_{(1)}^{2}=46, \mathrm{P}<0.0001$; health: $\left.\chi_{(1)}^{2}=48.8, \mathrm{P}<0.0001\right)$. Similarly, all three variables had a significant effect on the number of exit holes on trees (openness: $\chi_{(1)}^{2}=107, \mathrm{P}<0.0001$; health: $\chi_{(1)}^{2}=54.4, \mathrm{P}<0.0001$; diameter: $\chi_{(1)}^{2}=33.9, \mathrm{P}<$ $0.0001)$. Coefficient estimates of model parameters are shown in the Table 3 . The probability of occurrence as well as the number of exit holes increased with the diameter of a tree, with greater canopy openness around a tree and with decreasing state of health of a tree (Fig. 2).

\section{Site-specific patterns}

The models testing differences among the study sites showed that all three variables, tree health, diameter and openness, had a significant effect on the occurrence of $C$. cerdo exit holes on trees (health: $\chi_{(1)}^{2}=379, \mathrm{P}<0.0001$; diameter: $\chi_{(1)}^{2}=127, \mathrm{P}<0.0001$; openness: $\chi_{(1)}^{2}=24, \mathrm{P}<$ $0.0001)$ and site proved to have a significant effect $\left(\chi_{(2)}^{2}\right.$ $=20, \mathrm{P}<0.0001)$. Moreover, interaction terms of health

Table 2. Summary of the field data for the three sites studied, Soutok (floodplain), Rendezvous National Nature Monument (dry-sandy) and Podyjí National Park (dry-rocky), located in South Moravia, Czech Republic.

\begin{tabular}{lccc}
\hline & Floodplain & Dry-sandy & Dry-rocky \\
\hline Number of inspected trees & 198 & 515 & 353 \\
Number of trees with exit holes & 116 & 85 & 106 \\
Percentage of trees inhabited by C. Cerdo & 0.59 & 0.17 & 0.30 \\
Mean DBH (in cm) & 139 & 64 & 24 \\
Mean DBH of trees with exit holes (in cm) & 152 & 69 & 27 \\
Mean height (in m) & 18.3 & 18.8 & 7.5 \\
Number of exit holes recorded & 14337 & 579 & 508 \\
Number of exit holes up to 2.5 m & 4783 & 218 & 422 \\
Percentage of exit holes found up to 2.5 m & 0.33 & 0.38 & 0.83 \\
Mean number of exit holes per tree & 72.4 & 1.1 & 1.4 \\
Mean number of exit holes per inhabited tree & 123.6 & 6.8 & 4.8 \\
\hline
\end{tabular}


and diameter with site also had significant effects on the occurrence of exit holes (health : site : $\chi_{(2)}^{2}=33, \mathrm{P}=0.002$; diameter : site : $\left.\chi_{(2)}^{2}=19, \mathrm{P}=0.023\right)$.

Diameter, tree health and openness also had a significant effect on the number of exit holes on a tree (diameter: $\mathrm{F}_{(1,1064)}=1651, \mathrm{P}<0.0001$; health: $\mathrm{F}_{(1,1063)}=413, \mathrm{P}<$ 0.0001 ; openness: $\left.\mathrm{F}_{(1,1062)}=128, \mathrm{P}<0.0001\right)$, and again, site also proved to have a significant effect $\left(\mathrm{F}_{(2,1060)}=37.21\right.$, $\mathrm{P}<0.0001)$. Regarding interaction, only the interaction between health and site was significant $\left(\mathrm{F}_{(2,1058)}=3.84, \mathrm{P}\right.$ $=0.022)$. Coefficient estimates of model parameters are shown in Table 3.

The distance to the nearest occupied tree did not have a significant effect, either on the probability of occurrence of $C$. cerdo in trees $\left(\chi^{2}=0.3, \mathrm{P}=0.58\right)$, or on the number of exit holes $\left(\mathrm{F}_{(1,882)}=3.71, \mathrm{P}=0.054\right)$ (see Table $\mathrm{S} 1$ of the Supplementary Material for more details).

At all sites, the probability of occurrence and the number of exit holes increased with the diameter of a tree, with a

Table 3. Estimates of the parameters of the $(A)$ generalized linear mixed-effects models with binomial and Poisson distributions and for (B) generalized linear models with binomial and quasi-Poisson distributions, with standard errors, test statistics (Wald statistic, zvalue, t-value) and significance $(P)$. Only significant variables were included in the final models (see Results section for details).

\begin{tabular}{lrrrr}
\hline (A) General patterns & & & & \\
\hline Occurrence (binomial distribution) & & & \\
\hline Model parameter & Estimate & SE & $\begin{array}{r}\text { Wald } \\
\text { statistic }\end{array}$ & $P$ \\
\hline (Intercept) & -5.368 & 0.389 & 190.3 & $<0.0001$ \\
Diameter & 0.016 & 0.002 & 65.2 & $<0.0001$ \\
Openness & 0.171 & 0.052 & 10.9 & 0.001 \\
Health & 1.445 & 0.207 & 48.8 & $<0.0001$ \\
\hline Number of exit holes (Poisson distribution) & & \\
\hline Model parameter & Estimate & SE & Wald & \\
& & & statistic & \\
\hline (Intercept) & -1.227 & 0.878 & 1.95 & 0.16 \\
Openness & 0.151 & 0.016 & 89.54 & $<0.0001$ \\
Health & 0.754 & 0.058 & 170.56 & $<0.0001$ \\
Diameter & 0.016 & 0.003 & 33.94 & $<0.0001$ \\
\hline (B) Site-specific patterns & & & & \\
\hline
\end{tabular}

(B) Site-specific patterns

\begin{tabular}{lrrrr}
\hline Occurrence (binomial distribution) & & & \\
\hline Model parameter & Estimate & SE & z value & \multicolumn{1}{c}{$P$} \\
\hline (Intercept) & -7.726 & 0.854 & -9.05 & $<0.0001$ \\
Health & 1.179 & 0.149 & 7.94 & $<0.0001$ \\
Diameter & 0.122 & 0.023 & 5.28 & $<0.0001$ \\
Openness & 0.284 & 0.044 & 6.43 & $<0.0001$ \\
Site Dry-sandy & 0.622 & 1.179 & 0.53 & 0.598 \\
Site Floodplain & -1.278 & 1.507 & -0.85 & 0.396 \\
Health : Site Dry-sandy & 1.206 & 0.283 & 4.26 & $<0.0001$ \\
Health : Site Floodplain & 0.642 & 0.326 & 1.97 & 0.049 \\
Diameter : Site Dry-sandy & -0.103 & 0.025 & -4.09 & $<0.0001$ \\
Diameter : Site Floodplain & -0.091 & 0.025 & -3.70 & 0.0002 \\
\hline Number of exit holes (quasi-Poisson & distribution) & \\
\hline Model parameter & Estimate & SE & t value & $P$ \\
\hline (Intercept) & -2.940 & 0.859 & -3.42 & 0.0006 \\
Diameter & 0.013 & 0.001 & 11.12 & $<0.0001$ \\
Health & 0.874 & 0.246 & 3.55 & 0.0004 \\
Openness & 0.148 & 0.018 & 8.05 & $<0.0001$ \\
Site Dry-sandy & -0.517 & 1.022 & -0.51 & 0.613 \\
Site Floodplain & 2.255 & 0.883 & 2.55 & 0.011 \\
Health : Site Dry-sandy & 0.425 & 0.307 & 1.38 & 0.167 \\
Health : Site Floodplain & -0.079 & 0.251 & -0.31 & 0.753 \\
\hline & \multicolumn{5}{c}{} \\
\hline
\end{tabular}
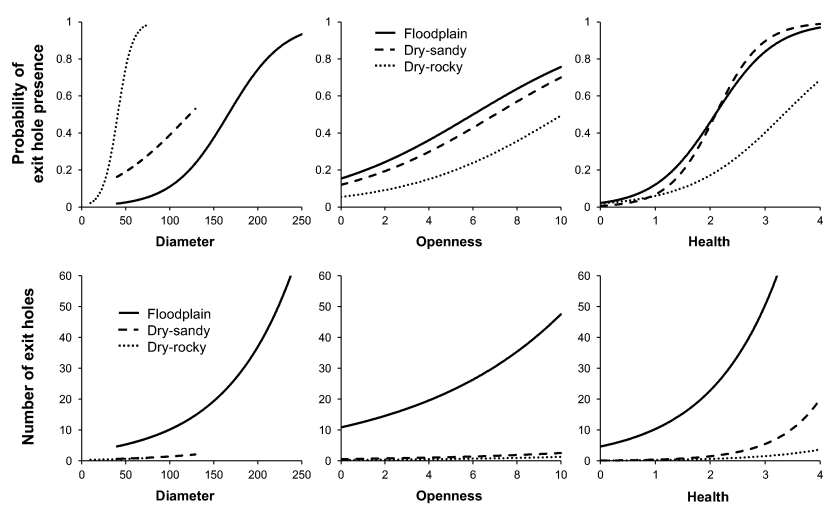

Fig. 3. Predicted probability of occurrence (top row) and number of $C$. cerdo exit holes (bottom row) in relation to three significant variables, site as a factor variable and their interactions; based on generalized linear models with binomial and quasi-Poisson distributions, respectively. Solid line - floodplain site, dashed line - drysandy site, dotted line - dry-rocky site.

more open canopy around a tree and with decreasing state of health of a tree, but the shapes of the relationship differed considerably among the sites studied (Fig. 3). For instance, at the dry-rocky site, the probability of occurrence exhibited a sharp increase at small diameters; at a $\mathrm{DBH}$ of $50 \mathrm{~cm}$ the probability was already higher than 0.50 . In contrast, at the floodplain site, the increase with diameter was very slow, reaching a probability of 0.50 at ca. $\mathrm{DBH}$ of $160 \mathrm{~cm}$. On the other hand, at the dry-rocky site, the probability of occurrence in relation to openness and state of health was lower or less steep than at the dry-sandy and floodplain sites. Regarding the number of exit holes, at the floodplain site there was a higher number of exit holes and constant increase with diameter, openness, and poorer state of health; the two dry sites had a comparatively lower number of exit holes (Fig. 3).

\section{Within-site effects}

In a separate analysis of data from the dry-sandy site, where there were three species of oaks, tree species proved to have a significant effect on both the occurrence and number of exit holes on a tree after all other significant variables; Analysis of occurrence - health: $\chi_{(1)}^{2}=210, \mathrm{P}$ $<0.0001$; openness: $\chi_{(1)}^{2}=28, \mathrm{P}=0.0001$; diameter $\chi_{(1)}^{2}=$ $4.4, \mathrm{P}=0.036$; species: $\chi_{(2)}^{2}=6.5, \mathrm{P}=0.039$. Analysis of the number of exit holes - health: $\mathrm{F}_{(1,513)}=569, \mathrm{P}<0.0001$; openness: $\mathrm{F}_{(1,512)}=174, \mathrm{P}<0.0001$; diameter: $\mathrm{F}_{(1,511)}=52.7$, $\mathrm{P}<0.0001$; species: $\chi_{(2,509)}^{2}=10.8, \mathrm{P}<0.0001$. On average, the probability of the occurrence of exit holes was greater on Quercus petraea $(0.24)$ and $Q$. robur $(0.29)$ than on $Q$. cerris $(0.10)$, and similarly, the mean number of exit holes was greater on $Q$. petraea (1.7) and $Q$. robur (2.4) than on $Q$. cerris $(0.5)$, indicating that $Q$. cerris is less exploited by the beetle in this area.

In a separate analysis of data from the dry-rocky site, slope orientation proved to have a significant effect on both occurrence and number of exit holes together with health and diameter, whereas openness did not have a significant effect at this site. Analysis of occurrence - slope: $\chi_{(4)}^{2}=$ 128.5, $\mathrm{P}<0.0001$; health: $\chi_{(1)}^{2}=45.6, \mathrm{P}<0.0001$; diameter 
Table 4. The results of the generalized linear models with binomial and (quasi-)Poisson distributions testing $(A)$ the effect of species of oak (Quercus cerris, Q. petraea, Q. robur) on the probability of occurrence and the number of Cerambyx cerdo exit holes on trees at the dry-sandy site, and $(B)$ the effect of slope orientation (East, North, South, West, flat) on the probability of occurrence and the number of $C$. cerdo exit holes on trees at the dry-rocky site. The table gives estimates of the coefficients of model parameters with their standard errors, test statistics (z-value, t-value) and significance $(P)$. Only significant variables were included in the final models (see the Results section for details).

\begin{tabular}{|c|c|c|c|c|}
\hline \multicolumn{5}{|c|}{ (A) Dry-sandy site (effect of species of oak) } \\
\hline \multicolumn{5}{|c|}{ Occurrence (binomial distribution) } \\
\hline Model parameter & Estimate & SE & $z$ value & $P$ \\
\hline (Intercept) & -8.85 & 1.1187 & -7.91 & $<0.0001$ \\
\hline Health & 2.47 & 0.273 & 9.05 & $<0.0001$ \\
\hline Openness & 0.44 & 0.087 & 5.02 & $<0.0001$ \\
\hline Diameter & 0.03 & 0.0109 & 2.77 & 0.006 \\
\hline Species petraea & 1.17 & 0.4853 & 2.4 & 0.016 \\
\hline Species robur & 0.73 & 0.4283 & 1.71 & 0.088 \\
\hline \multicolumn{5}{|c|}{ Number of exit holes (Poisson distribution) } \\
\hline Model parameter & Estimate & SE & z value & $P$ \\
\hline (Intercept) & -5.57 & 0.34536 & -16.14 & $<0.0001$ \\
\hline Health & 1.34 & 0.06422 & 20.81 & $<0.0001$ \\
\hline Openness & 0.31 & 0.02593 & 11.91 & $<0.0001$ \\
\hline Diameter & 0.03 & 0.00332 & 8.48 & $<0.0001$ \\
\hline Species petraea & 0.74 & 0.18957 & 3.88 & 0.0001 \\
\hline Species robur & 0.68 & 0.16636 & 4.08 & $<0.0001$ \\
\hline \multicolumn{5}{|c|}{ (B) Dry-rocky site (effect of slope orientation) } \\
\hline \multicolumn{5}{|c|}{ Occurrence (binomial distribution) } \\
\hline Model parameter & Estimate & SE & $z$ value & $P$ \\
\hline (Intercept) & -24.13 & 1633.62 & -0.01 & 0.99 \\
\hline Slope flat & 16.68 & 1633.62 & 0.01 & 0.99 \\
\hline Slope north & -0.05 & 2218.327 & 0 & 0.99 \\
\hline Slope south & 18.78 & 1633.62 & 0.01 & 0.99 \\
\hline Slope west & 21.34 & 1633.62 & 0.01 & 0.99 \\
\hline Health & 1.04 & 0.1593 & 6.53 & $<0.0001$ \\
\hline Diameter & 0.10 & 0.0248 & 4.16 & 0.00003 \\
\hline \multicolumn{5}{|c|}{ Number of exit holes (quasi-Poisson distribution) } \\
\hline Model parameter & Estimate & SE & $\mathrm{t}$ value & $P$ \\
\hline (Intercept) & -20.60 & 887.00 & -0.02 & 0.98 \\
\hline Slope flat & 16.40 & 887.00 & 0.02 & 0.99 \\
\hline Slope north & 0.10 & 1210.00 & 0 & 1 \\
\hline Slope south & 18.30 & 887.00 & 0.02 & 0.98 \\
\hline Slope west & 18.70 & 887.00 & 0.02 & 0.98 \\
\hline Health & 0.72 & 0.05 & 14.73 & $<0.0001$ \\
\hline Diameter & 0.04 & 0.00 & 10.54 & $<0.0001$ \\
\hline
\end{tabular}

$\chi_{(1)}^{2}=20, \mathrm{P}<0.0001$; openness: $\chi_{(1)}^{2}=0.7, \mathrm{P}=0.42$. Analysis of the number of exit holes - slope: $\mathrm{F}_{(4,348)}=41.7, \mathrm{P}<$ 0.0001; health: $\mathrm{F}_{(1,347)}=82.6, \mathrm{P}<0.0001$; diameter: $\mathrm{F}_{(1,346)}$ $=27.2, \mathrm{P}<0.0001$; openness: $\mathrm{F}_{(1,345)}=0.01, \mathrm{P}=0.91$. On average, the probability of the occurrence of exit holes was greater for trees on slopes oriented to the West $(0.92)$ and South (0.48) than for trees on flat ground (0.09); no exit holes were found on trees on slopes oriented to the North and East. Similarly, the mean number of exit holes was greater on trees on slopes oriented to the West (3.92) and South (2.45) than on trees on flat ground (0.22). These results indicate that in hilly terrain, trees are more prone to be exploited by the beetle if they grow on sun-facing and thus warmer slopes.

Coefficient estimates of model parameters for analyses of both dry-sandy and dry-rocky sites are shown in Table 4.

\section{DISCUSSION}

The present study extends the knowledge on habitat use of the great capricorn beetle, an endangered saproxylic beetle regarded as a specialist feeder on veteran trees (Buse et al., 2007). It corroborates the main findings of previous studies, such as that decreasing health state of a tree, its increasing diameter and sunlight availability (herein represented by the openness and slope orientation) favour the presence of C. cerdo in trees (Buse et al., 2007; Albert et al., 2012). More importantly, however, it reveals a high between-site variability in characteristics of trees exploited by this beetle, principally the variability in their diameter. This implies that although we can well describe the general patterns in habitat use and describe the beetle's fundamental niche, for the survival of local populations the local conditions and the beetle's realized niche are what is important and thus should be considered in conservation management planning. Below, we discuss the findings and their implications for the conservation of C. cerdo and potentially other veteran tree specialists.

\section{Diameter of inhabited trees and the importance of large trees}

The probability of the presence of exit holes on a tree with respect to its diameter differed substantially among the sites. The number of exit holes on a tree, on the other hand, was affected mainly by tree diameter, rather than locality, as suggested by the positive relationship between tree diameter and the number of exit holes (Fig. 3).

We consider the local soil and humidity conditions as the most likely factors behind the differences in the diameter of trees exploited by C. cerdo. The floodplain and the dryrocky sites represent extreme oak habitats. At the former site, nutrient rich, deep soils and a high water table offer optimal conditions for rapid growth, resulting in trees of large dimensions (Altman et al., 2016). The dry-rocky site, on the other hand, is characterized by stressful conditions due to nutrient poor, shallow and desiccating soils, which result in slow growth and low vitality of the trees, allowing for colonisation of small trees by $C$. cerdo. Due to differences in the rate of growth between the two sites, the trees may reach the same probability of occupancy at a similar age (estimated by dividing the DBH of a tree with a particular probability of occurrence by average ring width), but the trees at the dry-rocky site are just smaller. At the dry-sandy site, tree growth was nearly as slow as at the dry-rocky site. The conditions at that site are, however, relatively stable. The trees thus remain vigorous for longer; they are likely to grow larger and become suitable for $C$. cerdo later than trees at the dry-rocky site.

The positive relationship between tree diameter and the number of exit holes (Fig. 3) indicates that tree diameter limits the number of $C$. cerdo exit holes via the amount of substrate suitable for larval development. There were about 30 times more exit holes on a large tree $(\sim 150 \mathrm{~cm} \mathrm{DBH})$ than on a small tree $(\sim 30 \mathrm{~cm} \mathrm{DBH})$. Although the number of exit holes may not be a direct measure of the number of beetles that developed in a tree, the two numbers are rather 
closely related. Moreover, at the dry-rocky site, trees were shorter in height and most of the exit holes (83\%) were found up to $2.5 \mathrm{~m}$ above the ground, whereas at the drysandy and floodplain sites only one-third (33-38\%) of all exit holes were found up to $2.5 \mathrm{~m}$ above the ground.

As substantially more individuals of $C$. cerdo develop in large trees these represent larger habitat patches than small trees. Regarding the metapopulation theory (Hanski \& Ovaskainen, 2003), we hypothesize that the dimensions of trees may have an effect on population dynamics. It implies that the number of trees needed for the survival of C. cerdo populations is lower at sites with large trees than at sites with small trees. On large trees, individuals of $C$. cerdo are more likely to encounter a mate without moving to another tree. Thus, the need for dispersal may be higher in populations living on small trees (Clobert et al., 2004; Bowler \& Benton, 2005). Some authors even suggest that insect populations occupying small habitat patches may have a greater tendency to disperse in order to avoid inbreeding (Pusey \& Wolf, 1996; Feldhaar \& Schauer, 2018), because in small patches the chance that individuals are closely related may be higher than in large patches. However, this theory seems to have limited support in the case of $C$. cerdo. On very small trees, only a single individual per year may emerge, whereas on large trees the probability of two emerging adults originating from the same hatch, and therefore closely related, may be higher. But in any case, if the small dimensions of trees drive the beetle to disperse more frequently, the populations inhabiting small trees are probably more likely to be susceptible to the effects of habitat fragmentation and isolation (Clobert et al., 2001; Ranius, 2006), because dispersal always increases the risk of predation and abandoning a suitable habitat.

Published data indicate the existence of a relationship between diameter of inhabited trees and the incidence of dispersal for another veteran tree specialist, the hermit beetle (Osmoderma eremita). In Sweden, an average inhabited tree (with DBH of $130 \mathrm{~cm}$ ) hosted $\sim 11$ beetles and the population structure was described as a metapopulation with low dispersal between trees (Ranius, 2000, 2007; Hedin et al., 2008). In Italy, where the inhabited trees were smaller (mean DBH of $65 \mathrm{~cm}$ ) an average tree hosts only 0.5-2 individuals (Chiari et al., 2013) and the incidence of dispersal was higher (Chiari et al., 2012). Although these differences in dispersal rate were attributed to differences in the climate at the northern and southern edges of the beetle's distributional range, they might also reflect relatively low numbers of beetles per tree, determined by the parameters of the available trees. This needs to be studied further, by comparing the mobility of beetles from populations that exploit large and small trees growing in areas with the same climate.

Although most of the saproxylic species associated with large, veteran trees are also at least occasionally able to utilize small trees (Sláma, 1998; Harvey et al., 2011; Chiari et al., 2013), it is the large trees that are likely to host the bulk of their populations and increase the probability of their survival. This is probably one of the main reasons for the great importance of large trees for C. cerdo (Buse et al., 2007; Albert et al., 2012) and probably also saproxylic biodiversity as a whole (Eckelt et al., 2018; Parmain \& Bouget, 2018).

\section{Effect of species of oak}

The presence of exit holes is also associated with the species of oak, as the Turkey oak (Quercus cerris) was less exploited by $C$. cerdo than the sessile and pedunculate oaks. Within the genus Quercus, the Turkey oak is distantly related to the sessile and pedunculate oaks (Oh \& Manos, 2008; Denk \& Grimm, 2010) and its wood differs from that of most other oaks by its lower durability and tendency to split (Ferrari et al., 2013). Such wood properties may have a potentially adverse effect on $C$. cerdo, as is also proposed for the red oak (Quercus rubra) (Oleksa \& Klejdysz, 2017). This agrees with observations from Slovakia and Hungary, where this beetle is rather rare in stands of Turkey oak and even senescent, large Turkey oaks often lack any signs of the presence of C. cerdo (L. Cizek, pers. obs.). We attribute the observed pattern rather to the avoidance of Turkey oak by $C$. cerdo than to a lower detectability of old exit holes due to the faster decay of its wood, as larval galleries of $C$. cerdo reach deep into the wood and are detectable for decades. Turkey oak made up about $60 \%$ of the oaks inspected at the dry-sandy site and the lower occupancy of Turkey oaks probably has partially affected the results for this site. Similar occupancy, wood properties and the relatedness of pedunculate and sessile oaks, however, justify neglecting species of oak in data analyses of the two other study sites.

\section{Distance to the nearest occupied tree}

In contrast to Buse et al. (2007) or Oleksa \& Klejdysz (2017), we did not find any effect of distance to the nearest occupied tree on the probability of occurrence or on the number of exit holes of $C$. cerdo on trees. While traditionally the dispersal capacity of saproxylic insects was considered to be limited, recent studies show that dispersal may be strongly dependent on the life history of the species or group studied and is often greater than thought in the past (Feldhaar \& Schauer, 2018; Schauer et al., 2018). This is also the case for $C$. cerdo, for which a radio-tracking study (Drag \& Cizek, 2018) revealed dispersal over greater distances than reported in a previous mark-recapture study (Torres-Vila et al., 2017). Therefore, the size of our three study sites might have been too small to reveal the dispersal limitations of C. cerdo.

\section{Implications for conservation}

Our findings indicate that site conditions affect occupancy and potentially population dynamics, and therefore must be taken into consideration in developing management strategies for the conservation of $C$. cerdo. At inhabited sites, an inventory of all available oaks should be performed, specifying how many trees are occupied by the beetle, what is their state and diameter, and also what are the trees potentially suitable for $C$. cerdo there. As longterm planning is necessary for efficient conservation of the organisms associated with veteran trees, it is also impor- 
tant to record the numbers and diameters of young trees in order to identify potential gaps in the future availability of suitable trees.

Since mortality of veteran trees exceeds their recruitment in the long term (Siitonen \& Ranius, 2015), there is a need to bridge the temporal gap in their availability (Gibbons et al., 2008; Miklín \& Č́žzek, 2014). Ensuring the continuity of large veteran trees is always the most desirable, though rarely an available option, simply because it is impossible to manipulate tree diameter and volume in the short term. Our results, nevertheless, indicate that even small (or young) trees may be utilized by $C$. cerdo beetle if they are exposed to sunshine and in poor health. Both exposure to sun and tree health can be manipulated. Thus, it is possible to bridge the gap in the availability of large veteran trees by creating large numbers of small trees that are exposed to sunshine and in poor health. In stands occupied by $C$. cerdo, opening the canopy by partial cutting or thinning should be followed by practices like, e.g. pollarding, grazing, bark-stripping, partial bark-ringing or fire (Smith \& Sutherland, 1999; Helm et al., 2011; Gruebler et al., 2013; Sebek et al., 2013; Reichmuth et al., 2018).

At sites where $C$. cerdo inhabits small trees that sustain fewer beetles, greater areas of habitat and higher densities of suitable trees are needed to sustain these local populations. At sites where C. cerdo occupies large old trees, management should primarily focus on sustaining such trees to keep them alive as long as possible (Read, 2000; Lindenmayer, 2017) but also on taking care of other oaks in the surroundings. Increased canopy closure is a common problem in European woodlands (Altman et al., 2013; Miklín \& Čížek, 2014; Chudomelová et al., 2017). It decreases the suitability of the existing veteran trees for $C$. cerdo and compromises their survival (Miklín et al., 2018) and also hinders the establishment of new generations of veteran trees. Maintenance of open oak woodlands is thus the key for the conservation of C. cerdo in temperate climates. There are several options for keeping or restoring the open structure of woodlands, such as grazing, significant thinning, coppicing, or prescribed burning (Vera, 2000; Lindbladh et al., 2003; Hédl et al., 2010; Hanberry \& Abrams, 2018). The canopy of large open-grown oaks that are currently in closed-canopy conditions should be freed from the rest of the canopy by gradually and carefully clearing a circle or partial circle around them, a technique called "haloing" (Lonsdale, 2013). The lifespan of old trees can be prolonged by crown reduction, which reduces the risk of trunk collapse, such as pollarding or shredding (Lonsdale, 2013; Sebek et al., 2013). Moreover, in hilly areas where C. cerdo is present, conservation effort should target primarily South- and West-facing slopes, and in stands composed of several species of oak, the sessile and pedunculate oaks should be of a primary interest.

It is important to stress that the above-mentioned recommendations apply principally to woodlands in the temperate zone, where $C$. cerdo is considered to be a threatened species. In Mediterranean regions of Europe, the requirements of this beetle may differ significantly. Firstly, $C$. cerdo there usually exploits other species of oak, mostly holm oak (Quercus ilex) and cork oak (Q. suber) (Sallé et al., 2014; Torres-Vila et al., 2017). Secondly, in a warm climate, even trees on East- and North-facing slopes may be utilized. Finally, in some parts of the Mediterranean, $C$. cerdo is considered a pest, being one of the principal insect species responsible for oak decline (Sallé et al., 2014; Duque-Lazo \& Navarro-Cerrillo, 2017) and thus not a species in need of protection.

\section{Study limitations}

With respect to the different rates of growth of trees recorded at different sites, it would be interesting to relate the exploitation of trees by $C$. cerdo directly to tree age, not their diameter (Horák, 2017). However, this approach would require coring and analysing hundreds of trees, which is beyond the scope of this study. And it is, unfortunately, a general limitation in most studies relating habitat use of woodland biota to the diameter of trees growing under different conditions or managements (Jüriado et al., 2009; Nascimbene et al., 2013; Horák, 2017; Nordén et al., 2018). Based on the average ring widths (growth rate) measured for our sites, the trees at dry sites grew about three times slower than at the floodplain site and the trees on floodplains thus reach large dimensions sooner than those on the dry sites. But when comparing particular occurrence probabilities divided by average ring width, trees at the dry-rocky and the floodplain sites may have a similar occupancy by C. cerdo at a similar age, and trees at the drysandy site reach such probabilities later.

Further, it would be interesting to compare data from more sites. The dry-sandy and dry-rocky sites are, however, the only such sites hosting populations of $C$. cerdo in the Czech Republic, the closest similar sites being further east in Slovakia or Hungary. Although there are sites with C. cerdo inhabiting smaller trees in Southern Europe, they are occupied also by other large species of Cerambyx $(C$. miles, or $C$. welensii) with exit holes indistinguishable from those of C. cerdo. Most studies on the ecology of large saproxylic beetles are based on data collected at smaller spatial scales and less intensive in terms of the number of trees sampled (Ranius, 2001; Buse et al., 2007), indicating that a larger, continental-wide, approach is necessary. Such an approach is especially important for the saproxylic beetles listed in the EU's Habitat Directive (Council of the European Communities, 1992), which serve as focal species for conservation in most European countries.

\section{CONCLUSIONS}

The present study revealed that the habitat requirements of $C$. cerdo differ significantly among sites. Management aimed at conservation of its populations thus has to respect the local requirements of the beetle. Further, the study showed that large oaks are very important for $C$. cerdo because they represent large patches of suitable habitat. At the same time, however, it showed they are not a necessary condition for the survival of $C$. cerdo. It is principally exposure to sunshine and the state of health of the trees 
that is important for this beetle. Therefore, a tree becomes suitable for $C$. cerdo once it contains wood suitable for the development of its larvae, regardless of its diameter or age. This knowledge has important implications for the effective conservation of this species and possibly also other veteran tree specialists. It indicates that although focusing on ensuring the presence of large veteran trees is crucial, efforts might also be directed towards active creation of suitable conditions in smaller trees, especially if there are a low number of large trees at the site.

ACKNOWLEDGEMENTS. We would like to thank M. Škorpík, R. Stejskal, P. Dedek and V. Riedl for their advice and support, K. Novotná-Plátková and J. Plátek for help in the field, J. Altman for dendrochronology analyses, C. Bouget and P. Šmilauer for their comments, and P. Ríha for artwork. This study was funded by the Czech Science Foundation (grant No. 17-21082S) and the Institute of Entomology, BC CAS (RVO 60077344).

\section{REFERENCES}

Albert J., Platek M. \& Cizek L. 2012: Vertical stratification and microhabitat selection by the Great Capricorn Beetle (Cerambyx cerdo) (Coleoptera: Cerambycidae) in open-grown, veteran oaks. - Eur. J. Entomol. 109: 553-559.

AleXander K.N.A. 1998: The links between forest history and biodiversity: the invertebrate fauna of ancient pasture-woodlands in Britain and its conservation. In Kirby K.J. \& Watkins C. (eds): The Ecological History of European Forests. CABI, Wallingford, pp. 73-80.

Altman J., Hedl R., Szabo P., Mazurek P., Riedl V., Mullerova J., KoPeCKy M. \& DolezAL J. 2013: Tree-rings mirror management legacy: dramatic response of standard oaks to past coppicing in Central Europe. - PLoS ONE 8(2): e55770, 11 pp.

Altman J., Dolezal J. \& Cizek L. 2016: Age estimation of large trees: New method based on partial increment core tested on an example of veteran oaks. - Forest Ecol. Manag. 380: 82-89.

ANDERsson R. \& ÖSTLund L. 2004: Spatial patterns, density changes and implications on biodiversity for old trees in the boreal landscape of northern Sweden. - Biol. Conserv. 118: 443-453.

Barnouin T., Soldati F., Noblecourt T. \& Guiton B. 2017: First Inventory and Mapping of Osmoderma eremita (Scopoli, 1763) Populations in the Dominial Forest of Espinouse. Office National des Fôrets, Quillan, 24 pp.

Bergmeier E., Petermann J. \& Schröder E. 2010: A geobotanical survey of wood-pasture habitats in Europe: diversity, threats and conservation. - Biodiv. Conserv. 19: 2995-3014.

BiLy S. \& MehL O. 1989: Longhorn Beetles (Coleoptera, Cerambycidae) of Fennoscandia and Denmark. Fauna Entomologica Scandinavica 22, Brill, Leiden, 204 pp.

Bowler D.E. \& Benton T.G. 2005: Causes and consequences of animal dispersal strategies: relating individual behaviour to spatial dynamics. - Biol. Rev. Camb. Philos. 80: 205-225.

Buse J., Schroder T. \& Assmann B. 2007: Modelling habitat and spatial distribution of an endangered longhorn beetle - A case study for saproxylic insect conservation. - Biol. Conserv. 137: 372-381.

Buse J., Ranius T. \& Assmann B. 2008: An endangered longhorn beetle associated with old oaks and its possible role as an ecosystem engineer. - Conserv. Biol. 22: 329-337.

Cálix M., Alexander K.N.A., Nieto A., Dodelin B., Soldati F., Telnov D., Vazquez-Albalate X., Aleksandrowicz O., AudiSio P., Istrate P. ET AL. 2018: European Red List of Saproxylic Beetles. IUCN, Brussels, 12 pp.
Chiari S., Carpaneto G.M., Zauli A., Zirpoli G.M., Audisio P. \& Ranius T. 2012: Dispersal patterns of a saproxylic beetle, Osmoderma eremita, in Mediterranean woodlands. - Insect Conserv. Diver. 6: 309-318.

Chiari S., Zauli A., Mazziotta A., Luiselli L., Audisio P. \& CarPANETO G.M. 2013: Surveying an endangered saproxylic beetle, Osmoderma eremita, in Mediterranean woodlands: a comparison between different capture methods. - J. Insect Conserv. 17: 171-181.

Chudomelová M., Hédl R., Zouhar V. \& Szabó P. 2017: Open oakwoods facing modern threats: Will they survive the next fifty years? - Biol. Conserv. 210: 163-173.

Clobert J., Danchin E., Dhondt A. \& Nichols J.D. 2001: Dispersal. Oxford University Press, Oxford, 452 pp.

Clobert J., Ims R.A. \& Rousset F. 2004: Causes, mechanisms and consequences of dispersal. In Hanski I. \& Gaggiotti O.E. (eds): Ecology, Genetics, and Evolution of Metapopulations. Elsevier Academic Press, Burlington, MA, pp. 307-336.

Council of the European Communities 1992: Council Directive 92/43/EEC - On the Conservation of Natural Habitats and of Wild Fauna and Flora. URL: https://eur-lex.europa.eu/eli/ dir/1992/43 (last accessed 26 Feb. 2019).

Cromsigt J.P.G.M., Kerley G.I.H. \& Kowalczyk R. 2012: The difficulty of using species distribution modelling for the conservation of refugee species - the example of European bison. — Divers. Distrib. 18: 1253-1257.

Denk T. \& Grimm G.W. 2010: The oaks of western Eurasia: Traditional classifications and evidence from two nuclear markers. - Taxon 59: 351-366.

Drag L. \& CizeK L. 2015: Successful reintroduction of an endangered veteran tree specialist: Conservation and genetics of the Great Capricorn beetle (Cerambyx cerdo). - Conserv. Genet. 16: $267-276$.

DrAG L. \& CIZEK L. 2018: Radio-tracking suggests high dispersal ability of the great capricorn beetle (Cerambyx cerdo). $-J$. Insect. Behav. 31: 138-143.

Drobyshev I., Niklasson M., Linderson H., Sonesson K., KarlsSON M., NILSSON S.G. \& LANNER J. 2008: Lifespan and mortality of old oaks - combining empirical and modelling approaches to support their management in Southern Sweden. - Ann. For. Sci. 65: 401, 13 pp.

Duque-Lazo J. \& Navarro-Cerrillo R.M. 2017: What to save, the host or the pest? The spatial distribution of xylophage insects within the Mediterranean oak woodlands of Southwestern Spain. - Forest Ecol. Manag. 392: 90-104.

Eckelt A., Müller J., Bense U., Brustel H., Bussler H., Chittaro Y., Cizek L., Frei A., Holzer E., Kadej M. et al. 2018: "Primeval forest relict beetles" of Central Europe: a set of 168 umbrella species for the protection of primeval forest remnants. - J. Insect Conserv. 22: 15-28.

Ehnström B. \& Axelsson R. 2002: Insect Galleries in Bark and Wood. ArtDatabanken SLU, Uppsala, 512 pp. [in Swedish].

ElLWANGer G. 2008: Conservation status of saproxylic beetles listed in Annexes II and IV of the Habitats Directive at a national (Germany) and biogeographical level. In Buse J., Alexander K.N.A., Ranius T. \& Assmann T. (eds): Saproxlic Beetles: Their Role and Diversity. 5th Symposium and Workshop on the Conservation of Saproxylic Beetles, 14-16, June 2008, Lüneburg, Germany. Pensoft, pp. 107-118.

FeldhaAr H. \& Schauer B. 2018: Dispersal in saproxylic beetles. In Ulyshen M. (ed.): Saproxylic Insects: Diversity, Ecology and Conservation (Zoological Monographs). Springer, pp. 515-546.

Ferrari S., Allegretti O., Cuccui I., Moretti N., Marra M. \& Todaro L. 2013: A revaluation of turkey oak wood (Quercus 
cerris L.) through combined steaming and thermovacuum treatments. - BioResources 8: 5051-5066.

Freese A., Benes J., Bolz R., Cizek O., Dolek M., Geyer A., Gros P., Konvicka M., Liegl A. \& Stettmer C. 2006: Habitat use of the endangered butterfly Euphydryas maturna and forestry in Central Europe. - Anim. Conserv. 9: 388-397.

Gibbons P., Lindenmayer D.B., Fischer J., Manning A.D., WeinBerg A., Seddon J., Ryan P. \& Barrett G. 2008: The future of scattered trees in agricultural landscapes. - Conserv. Biol. 22: 1309-1319.

Gossner M.M., Lachat T., Brunet J., Isacsson G., Bouget C., Brustel H., Brandl R., Weisser W.W. \& Müller J. 2013: Current near-to-nature forest management effects on functional trait composition of saproxylic beetles in beech forests. Conserv. Biol. 27: 605-614.

Gruebler M.U., Schaller S., Keil H. \& Naef-Daenzer B. 2013 The occurrence of cavities in fruit trees: effects of tree age and management on biodiversity in traditional European orchards. - Biodivers. Conserv. 22: 3233-3246.

Hanberry B.B. \& Abrams M.D. 2018: Recognizing loss of open forest ecosystems by tree densification and land use intensification in the Midwestern USA. - Reg. Environ. Change 18: $1731-1740$.

HANSKI I. \& OvaSKAINEN O. 2003: Metapopulation theory for fragmented landscapes. - Theor. Popul. Biol. 64: 119-127.

Harvey D.J., Gange A.C., Hawes C.J. \& RinK M. 2011: Bionomics and distribution of the stag beetle, Lucanus cervus (L.) across Europe. - Insect. Conserv. Diver. 4: 23-38.

Hedin J., Ranius T., Nilsson S.G. \& Smith H.G. 2008: Restricted dispersal in a flying beetle assessed by telemetry. - Biodivers. Conserv. 17: 675-684.

HédL R., KopeckÝ M. \& KomÁReK J. 2010: Half a century of succession in a temperate oakwood: from species-rich community to mesic forest. - Divers. Distrib. 16: 267-276.

Helm Ch., Wilson G., Midgley J., Kruger L. \& Witjowski E.T.F. 2011: Investigating the vulnerability of an African savanna tree (Sclerocarya birrea ssp. caffra) to fire and herbivory. - Austral. Ecol. 36: 964-973.

Hojsgandd S., Halekoh U. \& Yan J. 2006: The R Package geepack for generalized estimating equations. - J. Stat. Softw. 15(2): $11 \mathrm{pp}$.

HoRÁK J. 2017: Insect ecology and veteran trees. - J. Insect Conserv. 21: 1-5.

HorÁk J., PAVlíčEK J., Kout J. \& Halda J.P. 2018: Winners and losers in the wilderness: response of biodiversity to the abandonment of ancient forest pastures. - Biodiv. Conserv. 27 . 3019-3029.

Irmler U., Heller K. \& Warning J. 1996: Age and tree species as factors influencing the populations of insects living in dead wood (Coleoptera, Diptera: Sciaridae, Mycetophilidae). Pedobiologia 40: 134-148.

Jurc M., Ogris N., Pavlin N. \& Borkovic D. 2008: Forest as a habitat of saproxylic beetles on Natura 2000 sites in Slovenia. - Rev. Ecol. Biol. Sol 63: 53-66.

JÜriado I., Litra J., PAal J. \& Suija A. 2009: Tree and stand level variables influencing diversity of lichens on temperate broadleaved trees in boreo-nemoral floodplain forests. - Biodiv. Conserv. 18: 105-125.

Кiмото T. \& Duthie-Holt M. 2006: Exotic Forest Insect Guidebook. Canadian Food Inspection Agency, Ottawa, 128 pp.

Kostanjsek F., Sebek P., Baranova B., Seric Jelaska L., Riedl V. \& CizeK L. 2018: Size matters! Habitat preferences of the wrinkled bark beetle, Rhysodes sulcatus, the relict species of European primeval forests. - Insect Conserv. Diver. 11: 545-553.
Lindbladh M., NikLasson M. \& Nilsson S.G. 2003: Long-time record of fire and open canopy in a high biodiversity forest in southeast Sweden. - Biol. Conserv. 114: 231-243.

LinDENMAYER D.B. 2017: Conserving large old trees as small natural features. - Biol. Conserv. 211: 51-59.

Lindenmayer D.B., Laurance W.F. \& Franklin J.F. 2012: Global decline in large old trees. - Science 338: 1305-1306.

Lindenmayer D.B., Laurance W.F., Franklin J.F., Likens G.E., Banks S.C., Blanchard W., Gibbons P., Ikin K., Blair D., MCBurney L. ET AL. 2014: New policies for old trees: Averting a global crisis in a keystone ecological structure - Conserv. Lett. 7: 61-69.

Lonsdale D. (ed.) 2013: Ancient and Other Veteran Trees: Further Guidance on Management. The Tree Council, London, $212 \mathrm{pp}$.

Macagno A.L.M., Hardersen S., Nardi G., Lo Giudice G. \& MAson F. 2015: Measuring saproxylic beetle diversity in small and medium diameter dead wood: The "grab-and-go" method - Eur. J. Entomol. 112: 510-519.

Manning A.D., Fischer J. \& Lindenmayer D.B. 2006: Scattered trees are keystone structures - Implications for conservation. - Biol. Conserv. 132: 311-321.

MikLín J. \& Č́̇̌̌EK L. 2014: Erasing a European biodiversity hotspot: Open woodlands, veteran trees and mature forests succumb to forestry intensification, succession, and logging in a UNESCO Biosphere Reserve. - J. Nat. Conserv. 22: 35-41.

MikLín J., MikLínovÁ K. \& ČížEK L. 2016: Land cover changes in the territory of Podyjí National Park between 1938 and 2014. Thayensia (Znojmo) 13: 59-80.

Miklín J., Sebek P., Hauck D., Konvicka O. \& Cizek L. 2018: Past levels of canopy closure affect the occurrence of veteran trees and flagship saproxylic beetles - Divers. Distrib. 24: 208-218.

Nascimbene J., Thor G. \& Nimis P.L. 2013: Effects of forest management on epiphytic lichens in temperate deciduous forests of Europe - A review. - Forest Ecol. Manag. 298: 27-38.

NordÉn B., JoRdAl J.B. \& EvJu M. 2018: Can large unmanaged trees replace ancient pollarded trees as habitats for lichenized fungi, non-lichenized fungi and bryophytes? - Biodiv. Conserv. 27: 1095-1114.

Он S.H. \& Manos P.S. 2008: Molecular phylogenetics and cupule evolution in Fagaceae as inferred from nuclear CRABS CLAW sequences. - Taxon 57: 434-451.

Oleksa A. \& Klejdysz T. 2017: Could the vulnerable great Capricorn beetle benefit from the introduction of the non-native red oak? - J. Insect Conserv. 21: 319-329.

Parmain G. \& Bouget C. 2018: Large solitary oaks as keystone structures for saproxylic beetles in European agricultural landscapes. - Insect Conserv. Diver. 11: 100-115.

Pusey A. \& Wolf M. 1996: Inbreeding avoidance in animals. Trends Ecol. Evol. 11: 201-206.

R CoRe TeAm 2017: R: A Language and Environment for Statistical Computing. $R$ Foundation for Statistical Computing, Vienna. URL: https://www.R-project.org/ (last accessed 12 Dec. 2017).

Ranius T. 2000: Minimum viable metapopulation size of a beetle, Osmoderma eremita, living in tree hollows. - Anim. Conserv. 3: $37-43$.

Ranius T. 2001: Constancy and asynchrony of Osmoderma eremita populations in tree hollows. - Oecologia 126: 208-215.

Ranius T. 2002: Population ecology and conservation of beetles and pseudoscorpions living in hollow oaks in Sweden. Anim. Biodiv. Conserv. 25: 53-68. 
Ranius T. 2006: Measuring the dispersal of saproxylic insects: a key characteristic for their conservation. - Popul. Ecol. 48: 177-188.

RANIUS T. 2007: Extinction risks in metapopulations of a beetle inhabiting hollow trees predicted from time series. - Ecography 30: 716-726.

RANius T. \& JANSSON N. 2000: The influence of forest regrowth, original canopy cover and tree size on saproxylic beetles associated with old oaks. - Biol. Conserv. 95: 85-94.

Ranius T., Aguado L.O., Antonsson K., Audisio P., Ballerio A., Carpaneto G.M., Сhobot K., Guurašin B., Hanssen O., Huijbregts H. Et AL. 2005: Osmoderma eremita (Coleoptera, Scarabaeidae, Cetoniinae) in Europe. - Anim. Biodiv. Conserv. 28.1: $44 \mathrm{pp}$

Read H. 2000: Veteran Trees: A Guide to Good Management. English Nature, Peterborough, $176 \mathrm{pp}$.

Reichmuth A., Henning L., Pinnel N., Bachmann M. \& Rogge D. 2018: Early detection of vitality changes of multi-temporal norway spruce laboratory needle measurements - the ringbarking experiment. - Remote Sens. 10(57): 19 pp.

Sallé A., NAgeleisen L.-M. \& Lieutier F. 2014: Bark and wood boring insects involved in oak declines in Europe: Current knowledge and future prospects in a context of climate change. - Forest Ecol. Manag. 328: 79-93.

SAMA G. 2002: Atlas of the Cerambycidae of Europe and the Mediterranean Area. Vol. 1: Northern, Western, Central and Eastern Europe, British Isles and Continental Europe from France (excl. Corsica) to Scandinavia and Urals. Kabourek, Zlín, $173 \mathrm{pp}$

Schauer B., Bong J., Popp C., Obermaier E. \& Feldhaar H. 2018: Dispersal limitation of saproxylic insects in a managed forest? A population genetics approach. - Basic Appl. Ecol. 32: $26-38$.

Schwenke W. 1974: Die Forstschädlinge Europas. Vol. 2: Käfer. Paul Parey, Hamburg, Berlin, 500 pp.

SCIEM 2012: Personal Analysis System for Treering Research (PAST4). URL: http://www.sciem.com/past/ (last accessed 12 Jul. 2018).

Sebek P., Altman J., Platek M. \& Cizek L. 2013: Is active management the key to the conservation of saproxylic biodiversity? Pollarding promotes the formation of tree hollows. - PLOS ONE 8(3): e60456, 6 pp.

Sebek P., Vodka S., Bogusch P., Pech P., Tropek R., Weiss M., Zimova K. \& CizeK L. 2016: Open-grown trees as key habitats for arthropods in temperate woodlands: The diversity, composition, and conservation value of associated communities. Forest Ecol. Manag. 380: 172-181.

Seibold S., Brandl R., Buse J., Hothorn T., Schmidl J., Thorn S. \& MÜlLER J. 2015: Association of extinction risk of saproxylic beetles with ecological degradation of forests in Europe. - Conserv. Biol. 29: 382-390.

SiItonen J. \& RANIUS T. 2015: The importance of veteran trees for saproxylic insects. In Kirby K.J. \& Watkins C. (eds): Europe's Changing Woods and Forests: From Wildwood to Managed Landscapes. CABI, Wallingford, pp. 140-153.

SLÁmA M.E.F. 1998: Longhorn Beetles (Cerambycidae) of the Czech Republic and Slovak Republic (Beetles - Coleoptera). By the Author, Krhanice, 383 pp. [in Czech].

SMith K.T. \& Sutherland E.K. 1999: Fire-scar formation and compartmentalization in oak. - Can. J. Forest Res. 29: 166171.

STARZYK J.R. 2004: Cerambyx cerdo (L., 1758), the great capricorn beetle. In Głowacinski Z. \& Nowacki J. (eds): Polish Red Book of Animals - Invertebrates. IOP PAN Kraków, AR Poznan, pp. 148-149 [in Polish].
Strausz M., Fiedler K., Franzen M. \& Wiemers M. 2012: Habitat and host plant use of the Large Copper Butterfly Lycaena dispar in an urban environment. - J. Insect Conserv. 16: 709-721.

Torres-Vila L.M., Mendiola-Diaz F.J. \& SÁnchez-GonzÁlez Á. 2017: Dispersal differences of a pest and a protected Cerambyx species (Coleoptera: Cerambycidae) in oak open woodlands: a mark-recapture comparative study. - Ecol. Entomol. 42: $18-32$.

VERA F.W.M. 2000: Grazing Ecology and Forest History. CABI, Wallingford, $506 \mathrm{pp}$.

Received August 24, 2018; revised and accepted February 4, 2019 Published online February 28, 2019

\section{Supplementary material}

Test of distance to the nearest tree

The following table shows results of the generalized linear models performed on a smaller dataset of 889 trees whose GPS coordinates were located. For each of these trees, we recorded the shortest distance to a measured tree occupied by Cerambyx cerdo (referred to as Nearest tree). This variable was included in the forward selection procedure together with, openness, diameter, state of health, site and their interactions with site, to assess their effect on occurrence of $C$. cerdo exit holes (model with binomial distribution) and number of exit holes on trees (model with quasiPoisson distribution). For the details, see Material and Methods in the original article.

Results of the models performed on the smaller dataset showed that the distance to the nearest occupied tree did not have an effect on the occurrence $\left(\chi^{2}=0.3, \mathrm{P}=0.58\right)$ or the number of exit holes of $C$. cerdo on trees $\left(\mathrm{F}_{(1,882)}=3.71, \mathrm{P}=0.054\right)$. See Table $\mathrm{S} 1$ for the test statistics.

Table S1. Test statistics for the parameters of the generalized linear models with binomial and quasi-Poisson distributions $\left(X^{2}\right.$ test or $F$ test), with degrees of freedom (d.f.) and significance level $(P)$.

\begin{tabular}{lccc}
\hline \multicolumn{4}{c}{ Occurrence (binomial distribution) } \\
\hline Model parameter & d.f. & $\mathrm{X}^{2}$ & $\mathrm{P}$ \\
\hline Health & 1 & 450.64 & $<0.0001$ \\
Diameter & 1 & 63.7 & $<0.0001$ \\
Openness & 1 & 22.63 & $<0.0001$ \\
Site & 2 & 13.99 & 0.0009 \\
Nearest tree & 1 & 0.3 & 0.581 \\
Health : Site & 2 & 13.39 & 0.001 \\
Diameter : Site & 2 & 9.43 & 0.009 \\
Openness : Site & 2 & 5.25 & 0.072 \\
Nearest tree : Site & 2 & 1.54 & 0.463
\end{tabular}

Number of exit holes (quasi-Poisson distribution)

\begin{tabular}{lccc}
\hline Model parameter & d.f. & $\mathrm{F}$ & $\mathrm{P}$ \\
\hline Diameter & 1,887 & 1320.74 & $<0.0001$ \\
Health & 1,886 & 375.03 & $<0.0001$ \\
Openness & 1,885 & 111.72 & $<0.0001$ \\
Site & 2,883 & 27.44 & $<0.0001$ \\
Nearest tree & 1,882 & 3.71 & 0.054 \\
Health : Site & 2,880 & 3.19 & 0.041 \\
Openness : Site & 2,878 & 2.81 & 0.061 \\
Nearest tree : Site & 2,876 & 2.06 & 0.128 \\
Diameter : Site & 2,874 & 0.82 & 0.443 \\
\hline
\end{tabular}

